\title{
Stereoselective disposition of ibuprofen enantiomers in infants
}

\author{
E. REY ${ }^{1}$, A. PARIENTE-KHAYAT ${ }^{1}$, L. GOUYET ${ }^{2}$, F. VAUZELLE-KERVROËDAN ${ }^{1}$, G. PONS ${ }^{1}$, Ph. D' ATHIS ${ }^{3}$, \\ M. C. DUBOIS ${ }^{2}$, I. MURAT ${ }^{2}$, C. LASSALE LA. MOEHRS $^{4}$, Cl. SAINT-MAURICE ${ }^{2} \&$ G. OLIVE ${ }^{1}$ \\ ${ }^{1}$ Département de Pharmacologie Périnatale et Pédiatrique, Hôpital Saint-Vincent de Paul, Paris, ${ }^{2}$ Département \\ d'Anesthésiologie, Hôpital Saint-Vincent de Paul et Hôpital Armand Trousseau, Paris, ${ }^{3}$ Département d'Informatique \\ Médicale, Hôpital du Bocage, Dijon and ${ }^{4}$ Boots-Pharma, Clinical Research Department, France
}

The pharmacokinetics of the enantiomers of ibuprofen were investigated after oral administration of a single $7.6 \pm 0.3 \mathrm{mg} \mathrm{kg}^{-1}$ dose of the racemate in 11 infants. Mean ( \pm s.d.) half-lives were $1.6 \pm 0.5 \mathrm{~h}$ for $\mathrm{S}(+)$ and $1.5 \pm 0.5 \mathrm{~h}$ for $\mathrm{R}(-)$ and mean $( \pm \mathrm{s} . \mathrm{d}$. AUC values were $31.5 \pm 14.3 \mathrm{mg} \mathrm{l}^{-1} \mathrm{~h}$ for $\mathrm{S}(+)$ and $36.6 \pm 13.8 \mathrm{mg} \mathrm{l}^{-1} \mathrm{~h}$ for $\mathrm{R}(-)$. Since plasma concentrations of the active $S(+)$-isomer were lower than those reported in adults, a higher dosage might be required in infants.

Keywords kinetics ibuprofen racemate enantiomers infants

\section{Introduction}

Ibuprofen is a chiral non-steroidal anti-inflammatory 2 arylpropionic acid. Its pharmacological activity with respect to cyclooxygenase inhibition is thought to reside almost exclusively in the $\mathbf{S}(+)$ configuration [1]. The disposition of this drug is stereoselective, the difference being due mainly to unidirectional metabolic inversion of the $\mathrm{R}(-)$ to the $\mathrm{S}(+)$ isomer [2]. The differential kinetics of the individual enantiomers have been studied in adults [3-5] but not in children. This study was designed to assess stereoselectivity in the pharmacokinetics of ibuprofen in infants following a single oral dose of the racemate administered for postoperative analgesia.

\section{Methods}

The study was performed in 11 (6 to 18 months old: seven males and four females) infants, weighing 9.5 $\pm 1.6 \mathrm{~kg}$. Each infant was in good health, as assessed by medical examination and laboratory tests, and none had any gastrointestinal, hepatic or renal disorder likely to interfere with ibuprofen absorption or disposition. None was receiving drugs known to induce or inhibit drug metabolism or to interfere with the assay of ibuprofen.

The protocol was approved by the hospital Ethics Committee (U.E.R., Cochin-Port-Royal) and signed informed written consent was obtained from each subject's parent.
The infants were anaesthetized for minor genitourinary surgery with halothane $1-3 \%$, vecuronium (70-100 $\left.\mu \mathrm{g} \mathrm{kg}^{-1}\right)$, phenoperidine $\left(10-30 \mu \mathrm{g} \mathrm{kg}^{-1}\right)$, and nitrous oxide $(n=7)$. Three received only halothane, vecuronium and nitrous oxide; one only halothane.

The infants received a mean $7.6 \pm 0.3 \mathrm{mg} \mathrm{kg}^{-1}$ oral dose of ibuprofen as a syrup formulation (Boots Pharma) given by a $2 \mathrm{ml}$ syringe in the recovery room.

Venous blood samples $(2 \mathrm{ml})$ were collected from an indwelling catheter, already placed for anaesthesia, into heparinised tubes at $0,1,2,3,4,6$ and $8 \mathrm{~h}$ after dosing. Urine samples were collected by spontaneous voiding in urine bags up to $12 \mathrm{~h}$ after drug ingestion.

Plasma samples were assayed for unresolved ibuprofen by h.p.l.c. Plasma $(0.2 \mathrm{ml})$ containing nordiazepam as internal standard and $0.6 \mathrm{ml}$ of $1 \mathrm{M}$ phosphoric acid was extracted with $6 \mathrm{ml}$ dichloromethane. After centrifugation the organic phase was evaporated to dryness under a stream of nitrogen at ambient temperature. The residue was dissolved in $100 \mu \mathrm{l}$ of the mobile phase (ammonium acetate buffer (100 mM, pH 5) $27 \% \mathrm{v} / \mathrm{v}$, methanol $73 \% \mathrm{v} / \mathrm{v})$. An ultrasphere ODS $5 \mu, 4.6 \times 250 \mathrm{~mm}$ column was used (Beckman), the flow rate was $1 \mathrm{ml} \mathrm{min}{ }^{-1}$ and detection was at $220 \mathrm{~nm}$. The repeatability of the assay was, respectively, $1.5 \%$ and $2.1 \%$ at $2 \mathrm{mg} \mathrm{l}^{-1}$ and 30 $\mathrm{mg} \mathrm{l}^{-1}(n=10)$. The reproducibility was $4.2 \%$ at 4 $\mathrm{mg} \mathrm{l}^{-1}$ and $4.5 \%$ at $22 \mathrm{mg} \mathrm{l}^{-1}(n=6)$. The limit of detection was $2 \mathrm{mg} \mathrm{l}^{-1}$ with a precision of $7.7 \%$. 
Ibuprofen enantiomer concentrations were measured in $200 \mu \mathrm{l}$ plasma samples by h.p.l.c. following formation of diastereoisomers as described by Avgerinos \& Hutt [6]. The extraction procedure and the chromatographic conditions were those described by Knadler \& Hall [7]. The repeatability was $4.6 \%$ $(\mathrm{S}(+))$ and $5.4 \%(\mathrm{R}(-))$ at $0.1 \mathrm{mg} \mathrm{l}^{-1} ; 4.1 \%(\mathrm{~S}(+))$ and $3.5 \%(\mathrm{R}(-))$ at $1 \mathrm{mg} \mathrm{l}^{-1}(n=10)$. The reproducibility was $6.1 \%(\mathrm{~S}(+))$ and $6.6 \%(\mathrm{R}(-))$ at $1.8 \mathrm{mg} \mathrm{l}^{-1} ; 5.8 \%$ $(\mathrm{S}(+))$ and $6.2 \%(\mathrm{R}(-))$ at $9.9 \mathrm{mg} \mathrm{l}^{-1}$. The limit of detection was $0.25 \mathrm{mg} \mathrm{l}^{-1}$ with a precision of $10.8 \%$ and $13.4 \%$, respectively, for $\mathrm{R}$ and $\mathrm{S}$ enantiomers. Since the measurement of the enantiomers was done after the analysis of the unresolved drug, the volume of plasma sample was diluted accordingly, and the volume used varied between $50 \mu \mathrm{l}$ and $200 \mu \mathrm{l}$.

Urine samples were assayed after acid hydrolysis as for plasma. Hydrolysis was carried out by incubating $0.1 \mathrm{ml}$ urine with $0.1 \mathrm{ml} \mathrm{HCl} 3 \mathrm{~N}$ at $100^{\circ} \mathrm{C}$ for $1 \mathrm{~h}$. The enantiomers were not measured in urine samples.

Pharmacokinetic and statistical analyses were performed using the TRIOMPHE program [8]. Elimination half-lives $\left(t_{1 / 2}\right)$ and AUC values were calculated by standard methods [9].

Spearman's correlation coefficients $(r)$ between AUC, $t_{1 / 2}$ and age were tested against zero. The relation between $\mathrm{S}(+)$ and $\mathrm{R}(-)$ concentrations was analysed by calculating the coefficient of linear correlation $(r)$, and by determining the principal axis of all the points by a principal component analysis.

\section{Results}

Mean plasma concentrations of unresolved ibuprofen and of the individual enantiomers are shown in Figure 1. Values of the sum of the individual enantiomer concentrations were $0-30 \%$ lower than those estimated using the non-chiral assay.

The plasma concentrations of $\mathrm{S}(+)$ drug were significantly lower than those of the $R(-)$ form $(R(-)=$ $-0.20+1.24 \mathrm{~S}, r=0.90, P<0.01) ; 95 \%$ confidence

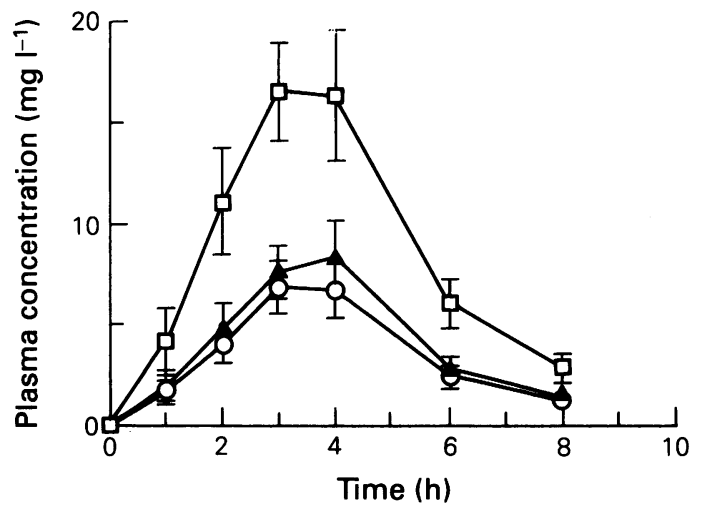

Figure 1 Mean ( \pm s.e. mean) plasma concentrations of total, $\mathrm{R}(-)$ and $\mathrm{S}(+)$ ibuprofen after a single oral dose of $7.6 \pm 0.3 \mathrm{mg} \mathrm{kg}^{-1}$ of racemate to infants $(n=11)$. $\square$ unresolved drug, $\Delta \mathrm{R}$-isomer, $\bigcirc \mathrm{S}$-isomer.

interval of the slope $(+1.10-+1.38)$. The maximum concentrations (unresolved ibuprofen: $24.4 \pm 6.6 \mathrm{mg}$ $\left.\mathrm{l}^{-1}, \mathrm{~S}(+): 9.7 \pm 2.9 \mathrm{mg} \mathrm{l}^{-1}, \mathrm{R}(-): 11.8 \pm 4.4 \mathrm{mg} \mathrm{l}^{-1}\right)$ were observed at $3 \mathrm{~h}$ (median; range: $2-4.1 \mathrm{~h}$ ). The AUC value for each enantiomer was approximately half that of the racemic drug. The half-lives were similar for unresolved ibuprofen and the individual enantiomers (unresolved: $1.6 \pm 0.4 \mathrm{~h} ; \mathrm{S}(+): 1.6 \pm 0.5$ $\mathrm{h} ; \mathrm{R}(-): 1.5 \pm 0.5 \mathrm{~h})$. The oral clearances were calculated for unresolved ibuprofen $\left(0.11 \pm 0.041 \mathrm{~h}^{-1} \mathrm{~kg}^{-1}\right)$ and the $R(-)$ enantiomer $\left(0.12 \pm 0.06 \mathrm{l} \mathrm{h}^{-1} \mathrm{~kg}^{-1}\right)$, but not for the $S(+)$ enantiomer as the fraction of metabolic inversion of $\mathrm{R}(-)$ to $\mathrm{S}(+)$ isomer is unknown; the oral clearance of the inactive $R(-)$ form was comparable with that of unresolved ibuprofen. For the same reason the apparent volume of distribution $(V / F)$ was calculated only for unresolved ibuprofen $\left(0.2 \pm 0.1 \mathrm{l} \mathrm{kg}^{-1}\right)$ and for the $\mathrm{R}(-)$ enantiomer $(0.3 \pm$ $0.21 \mathrm{~kg}^{-1}$ ) (Table 1).

Complete urine data were obtained in 7 of the 11 infants. The recoveries of unchanged drug $(0.31 \pm$ $0.08 \%)$ and conjugated ibuprofen $(3.5 \pm 1.4 \%)$ were low.

There was no significant correlation between the kinetic parameters and age.

Table 1 Pharmacokinetic parameters of ibuprofen after a single oral dose of racemic ibuprofen $\left(7.6 \pm 0.3 \mathrm{mg} \mathrm{kg}^{-1}\right)$ in infants $(n=11)$

\begin{tabular}{|c|c|c|c|c|c|c|c|c|c|c|c|c|c|c|c|c|c|c|}
\hline \multirow{2}{*}{$\begin{array}{l}\text { Patient } \\
\text { number }\end{array}$} & \multicolumn{3}{|c|}{$C_{\max }\left(m g l^{-l}\right)$} & \multicolumn{3}{|c|}{$\mathbf{t}_{\max }(h)$} & \multicolumn{3}{|c|}{$A U C\left(m g l^{-1} h\right)$} & \multicolumn{3}{|c|}{$t_{1 / 2}(h)$} & \multicolumn{3}{|c|}{$C L / \mathrm{F}\left(l h^{-1} k^{-I}\right)$} & \multicolumn{3}{|c|}{$\mathrm{V}_{\mathrm{z}} / \mathrm{F}\left(l k g^{-I}\right)$} \\
\hline & Rac* & $S$ & $R$ & $R a c^{*}$ & $S$ & $R$ & Rac* & $S$ & $R$ & Rac* & $S$ & $R$ & $R a c^{*}$ & $S$ & $R$ & $R a c^{*}$ & $S$ & $R$ \\
\hline 1 & 24.1 & 6.3 & 11.2 & 2.0 & 2.0 & 2.0 & 51.0 & 16.3 & 26.4 & 1.0 & 0.9 & 0.6 & 0.16 & - & 0.15 & 0.21 & - & 0.14 \\
\hline 2 & 17.6 & 7.6 & 6.5 & 3.0 & 3.0 & 3.0 & 51.2 & 21.3 & 18.2 & 1.6 & 1.2 & 2.1 & 0.15 & - & 0.21 & 0.34 & - & 0.65 \\
\hline 3 & 23.5 & 8.6 & 10.6 & 2.0 & 2.0 & 2.0 & 59.9 & 18.2 & 31.1 & 1.5 & 1.4 & 1.6 & 0.13 & - & 0.12 & 0.29 & - & 0.29 \\
\hline 4 & 29.8 & 12.3 & 13.5 & $3.1^{\dagger}$ & $3.1^{+}$ & $3.1^{\dagger}$ & 142.1 & 62.9 & 54.8 & 2.6 & 2.8 & 2.2 & 0.05 & - & 0.06 & 0.19 & - & 0.21 \\
\hline 5 & 23.1 & 7.1 & 10.0 & 2.0 & 2.0 & 2.0 & 88.6 & 28.4 & 42.1 & 1.6 & 2.3 & 1.5 & 0.08 & - & 0.09 & 0.19 & - & 0.19 \\
\hline 6 & 27.7 & 10.0 & 15.2 & 3.0 & 3.0 & 3.0 & 80.8 & 22.5 & 43.4 & 1.8 & 1.2 & 1.6 & 0.09 & - & 0.08 & 0.24 & - & 0.20 \\
\hline 7 & 24.2 & 15.1 & 10.4 & 3.0 & 3.0 & 3.0 & 82.6 & 48.5 & 38.0 & 1.4 & 1.5 & 1.4 & 0.09 & 一 & 0.10 & 0.18 & 一 & 0.19 \\
\hline 8 & 13.2 & 7.1 & 4.8 & 2.0 & 2.0 & 2.0 & 45.9 & 22.3 & 14.2 & 1.8 & 1.3 & 2.0 & 0.17 & - & 0.27 & 0.43 & - & 0.80 \\
\hline 9 & 34 & 11.8 & 19.6 & $4.1^{\dagger}$ & $4.1^{\dagger}$ & $4.1^{+}$ & 101.4 & 40.9 & 53.4 & 1.3 & 1.6 & 1.2 & 0.07 & - & 0.06 & 0.13 & - & 0.11 \\
\hline 10 & 17.9 & 8.1 & 10.2 & 4.0 & 4.0 & 4.0 & 65.7 & 33.0 & 30.1 & 1.4 & 1.8 & 1.1 & 0.12 & - & 0.13 & 0.24 & - & 0.20 \\
\hline 11 & 33.9 & 12.6 & 17.9 & 4.0 & 4.0 & 4.0 & 90.4 & 32.5 & 50.6 & 1.4 & 1.3 & 1.6 & 0.09 & - & 0.08 & 0.18 & - & 0.17 \\
\hline Mean & 24.4 & 9.7 & 11.8 & & & & 78.1 & 31.5 & 36.6 & 1.6 & 1.6 & 1.5 & 0.11 & & 0.12 & 0.2 & & 0.3 \\
\hline s.d. & 6.6 & 2.9 & 4.4 & & & & 28.1 & 14.3 & 13.8 & 0.4 & 0.5 & 0.5 & 0.04 & & 0.06 & 0.09 & & 0.2 \\
\hline
\end{tabular}

$*$ Rac $=$ unresolved ibuprofen.

${ }^{\dagger}$ The sampling time differed from the theoretical time by $5 \mathrm{~min}$. 


\section{Discussion}

Values of $C_{\max }$ and AUC, based on achiral assay, observed in the infants of this study and normalised for $\mathrm{mg} \mathrm{kg}^{-1}$ dose were similar to those observed in younger children [10] but about half of those reported in adults [11]. Values of $t_{\max }$ were longer than in children and adults. A relatively short $t_{1 / 2}$ is in agreement with data reported previously in children $[10,12,13]$ and adults [11]. The lower urinary recovery of conjugated drug in infants $(3.5 \pm 1.4 \%)$ compared with adults $(8.9 \pm 2.8 \%)$ [5] may be due to either immature glucuronidation, a lower bioavailability, or to an increased formation clearance of ibuprofen to other metabolites. This difference might be significant as the $95 \%$ confidence intervals do not overlap.

In infants, the plasma concentrations of the $\mathrm{S}(+)$ isomer were significantly lower than those of the $\mathrm{R}(-)$ form, while in adults the $\mathrm{S}(+)$ isomer predominates

\section{References}

1 Gaut ZN, Baruth H, Randall LO, Ashley C, Paulsrud JR. Stereoisomeric relationships among anti-inflammatory activity, inhibition of platelet aggregation, and inhibition of prostaglandin synthetase. Prostaglandins 1975; 10: 59-66.

2 Kaiser DG, Vangiessen GJ, Reischer RJ, Wechter WJ. Isomeric inversion of ibuprofen (R)-enantiomer in humans. J pharm Sci 1976; 65: 269-273.

3 Lee EJD, Williams K, Day R, Graham G, Champion D. Stereoselective disposition of ibuprofen enantiomers in man. Br J clin Pharmac 1985; 19: 669-674.

4 Geisslinger G, Schuster O, Stock KP, Loew D, Bach GL, Brune K. Pharmacokinetics of $\mathrm{S}(+)$ and $\mathrm{R}(-)$ ibuprofen in volunteers and first clinical experience in rheumatoid arthritis. Eur J clin Pharmac 1990; 38: 493-497.

5 Rudy AC, Knight PM, Brater DC, Hall SD. Stereoselective metabolism of ibuprofen in humans: administration of R-, S- and racemic ibuprofen. $J$ Pharmac exp Ther 1991; 259: 1133-1139.

6 Avgerinos A, Hutt AJ. Determination of the enantiomeric composition of ibuprofen in human plasma by high-performance liquid chromatography. J Chromatogr 1987; 415: 75-83.

7 Knadler MP, Hall SD. High-performance liquid chromatographic analysis of the enantiomers of flurbiprofen and its metabolites in plasma and urine. $J$ Chromatogr 1989; 494: 173-182.

8 Gex-Fabry M, Balant LP. Considerations on data analysis using computer methods and currently available software for personal computers. In Handbook of
[2, 3, 5, 14]. Explanations for this difference include impaired $R$ to $S$ inversion in the infant, and/or a higher clearance of the $S$ enantiomer. No relationship was found between the maximum plasma concentration ratio $S(+) / R(-)$ and the time to reach maximum plasma concentration, indicating no influence of a difference of gastro-intestinal absorption in children on the extent of inversion, as suggested by Jamali et al. in adults [14].

In adults, a linear relationship between plasma ibuprofen concentration and the degree of pain relief was reported by Laska et al. [15]. Since plasma concentrations of the active $S$ isomer are low in infants relative to adults a higher dosage might be required in infants.

We are grateful to Mrs M. Rufo for her skilful technical assistance and to Miss V. Andrieux for excellent secretarial assistance.
Experimental Pharmacology, Vol. 110; Pharmacokinetics of drugs. edited by P.G. Welling/L. P. Balant. Springer-Verlag, Berlin, Heidelberg 1994.

9 Gibaldi M. Biopharmaceutics and clinical pharmacokinetics, second edition. Lea and Febiger, Philadelphia 1977.

10 Brown RD, Wilson JT, Kearns GL, Eichler VF, Johnson VA, Bertrand KM. Single-dose pharmacokinetics of ibuprofen and acetaminophen in febrile children. $J$ clin Pharmac 1992; 32: 231-241.

11 Ochs HR, Greenblatt DJ, Matlis R, Weinbrenner J. Interaction of ibuprofen with the $\mathrm{H}-2$ receptor antagonists ranitidine and cimetidine. Clin Pharmac Ther 1985; 38: 648-651.

12 Mäkelä AL, Lempiaïnen M, Ylijoki H. Ibuprofen levels in serum and synovial fluid. Scand $J$ Rheumatology 1981; 39 Suppl.: 15-17.

13 Kelly MT, Walson PD, Edge JH, Cox S, Mortensen ME. Pharmacokinetics and pharmacodynamics of ibuprofen isomers and acetaminophen in febrile children. Clin Pharmac Ther 1992; 52: 181-189.

14 Jamali F, Singh NN, Pasutto FM, Russell AS, Coutts RT. Pharmacokinetics of ibuprofen enantiomers in humans following oral administration of tablets with different absorption rates. Pharm Res 1988; 5: 40-43.

15 Laska EM, Sunshine A, Marrero I, Olson N, Siegel C, McCormick N. The correlation between blood levels of ibuprofen and clinical analgesic response. Clin Pharmac Ther 1986; 40: 1-7.

(Received 7 July 1993, accepted 17 June 1994) 